Article

\title{
The Promoting Effect of Ishige sinicola on Hair Growth
}

\author{
Jung-Il Kang ${ }^{1}$, Eun-JI Kim ${ }^{1}$, Min-Kyoung Kim ${ }^{1}$, You-Jin Jeon ${ }^{2,3}$, Sung-Myung Kang ${ }^{3}$, \\ Young-Sang Koh ${ }^{1}$, Eun-Sook Yoo ${ }^{1}$ and Hee-Kyoung Kang ${ }^{1, *}$
}

1 Department of Medicine, School of Medicine, Institute of Medical Sciences, Jeju National University, 102 Jejudaehakno, Jeju 690-756, Korea; E-Mails: asdkji@hanmail.net (J.-I.K.); ejk8730@naver.com (E.-J.K.); loveis6776@hanmail.net (M.-K.K.); yskoh7@jejunu.ac.kr (Y.-S.K.); eunsyoo@jejunu.ac.kr (E.-S.Y.)

2 Aqua Green Technology Co. Ltd., 209 Jeju Bio-Industry Center, 102 Jejudaehakno, Jeju 690-121, Korea; E-Mail: youjinj@jejunu.ac.kr

3 Department of Marine Life Science, Jeju National University, 102 Jejudaehakno, Jeju 690-756, Korea; E-Mail: tjdaud81@hanmail.net

* Author to whom correspondence should be addressed; E-Mail: pharmkhk@jejunu.ac.kr; Tel.: +82-64-754-3846; Fax: +82-64-702-2687.

Received: 24 April 2013; in revised form: 8 May 2013 / Accepted: 9 May 2013 /

Published: 24 May 2013

\begin{abstract}
This study was conducted to evaluate the promoting effect of Ishige sinicola, an alga native to Jeju Island, Korea, on hair growth. When vibrissa follicles were cultured in the presence of $I$. sinicola extract for 21 days, I. sinicola extract increased hair-fiber length. After topical application of I. sinicola extract onto the back of C57BL/6 mice, anagen progression of the hair shaft was induced. The I. sinicola extract significantly inhibited the activity of $5 \alpha$-reductase. Treatment of immortalized vibrissa dermal papilla cells (DPCs) with $I$. sinicola extract resulted in increase of cell proliferation, which was accompanied by the increase of phospho-GSK3 $\beta$ level, $\beta$-catenin, Cyclin E and CDK2, whereas $\mathrm{p} 27^{\mathrm{kip} 1}$ was down-regulated. In particular, octaphlorethol A, an isolated component from the I. sinicola extract, inhibited the activity of $5 \alpha$-reductase and increased the proliferation of DPCs. These results suggest that $I$. sinicola extract and octaphlorethol A, a principal of I. sinicola, have the potential to treat alopecia via the proliferation of DPCs followed by the activation of $\beta$-catenin pathway, and the $5 \alpha$-reductase inhibition.
\end{abstract}

Keywords: Ishige sinicola; hair growth; dermal papilla cells; $\beta$-catenin; $5 \alpha$-reductase 


\section{Introduction}

Recently, there have been an increasing number of people suffering from hair loss, which has mostly emerged from psychological and physical stress [1]. Nevertheless, the underlying causes of baldness are poorly understood. Many materials have been used to cure alopecia. However, only two drugs so far have been approved for hair loss treatment by the Food and Drug Administration (FDA, Rockville, MD, USA); finasteride and minoxidil [2,3]. Finasteride, a type II 5 $\alpha$-reductase inhibitor, was initially used for curing prostatic hypertrophy [4], but later found to stimulate hair growth in men with androgenetic alopecia (AGA), which is the most common type of alopecia in men over the age of 40 [4-6]. Minoxidil, a potassium channel opener was developed as an anti-hypertensive. Moreover, it was also found to stimulate hair growth by the opening of ATP-sensitive $\mathrm{K}^{+}$-channel [7,8], the up-regulation of vascular endothelial growth factor (VEGF) [9] and the activation of $\beta$-catenin pathway [10] in dermal papilla cells (DPCs). The DPCs are mesenchymally-derived cells which play important roles in the morphogenesis, regeneration, and growth of hair [11]. Han et al. reported that minoxidil has proliferative and anti-apoptotic effects on DPCs [12]. Several natural products were also reported to promote hair growth via the proliferation of DPCs [13-15]. Wnt/ $\beta$-catenin plays an important role in hair growth, regeneration as well as cell proliferation [16-18]. $\beta$-Catenin is a main component of the Wnt pathway, and the level of $\beta$-catenin is regulated by degradation complexes such as adenomatous polyposis coli (APC), glycogen synthase kinase-3 $\beta$ (GSK-3 $\beta$ ), axin, and casein kinase I. Accumulation of nuclear $\beta$-catenin results in the activation of target genes such as cyclin D1 and c-myc $[19,20]$. Cell cycle regulation is a crucial event for cell proliferation and is tightly regulated by cyclin/cyclin-dependent kinases (CDKs) and CDK inhibitors [21]. Migogen-induced cell cycle progression can be inhibited by $\mathrm{p} 27^{\mathrm{kip} 1}$, a CDK inhibitor, which contributes to inhibit cell proliferation $[21,22]$.

To develop new therapies to enhance hair growth, we screened the extracts of Jeju algae and discovered that Ishige sinicola has the potential to promote hair growth. I. sinicola, a brown alga, was reported to have anti-bacterial and anti-inflammatory effects against acne [23]. Octaphlorethol A, a component from I. sinicola, was reported to induce anti-diabetic activity in skeletal muscle [24]. However, the effect of I. sinicola and the bio-active components of I. sinicola on the promotion of hair growth have not yet been reported. Therefore, the present study was carried out to investigate the promoting effect of $I$. sinicola extract and as an active component regarding hair growth.

\section{Results}

\subsection{The Effect of I. sinicola Extract on the Hair-Fiber Elongation of Rat Vibrissa Follicle}

To determine whether I. sinicola extract could promote hair growth, we examined the effect of I. sinicola extract using an organ culture of the rat vibrissa follicle. When rat vibrissa follicles were treated with various concentrations of I. sinicola extract for 3 weeks, in particular, the hair-fiber length of the vibrissa follicles treated with $1 \mu \mathrm{g} / \mathrm{mL}$ of $I$. sinicola extract significantly increased compared with the control (Figure 1). However, $100 \mu \mathrm{g} / \mathrm{mL}$ of $I$. sinicola extract decreased the hair-fiber length compared with the control. 
Figure 1. The elongation effect of $I$. sinicola extract on the hair-fiber length of rat vibrissa follicle. Individual vibrissa follicles from Wistar rats were microdissected and then cultured in William's E medium at $37{ }^{\circ} \mathrm{C}$ under $5 \% \mathrm{CO}_{2}$. Vibrissa follicles were then treated with $I$. sinicola extract $(1,10$ and $100 \mu \mathrm{g} / \mathrm{mL})$ for 21 days. Stimulation with minoxidil served as a positive control. All experiments were performed in triplicate. The difference in the length of vibrissa follicles of the vehicle-treated control group on day 21 was taken to be $100 \%$. Data are presented as the percentage of the length of the treated follicles based on the mean length of the control follicles \pm the S.E. ${ }^{*} p<0.05 v$ s. control.

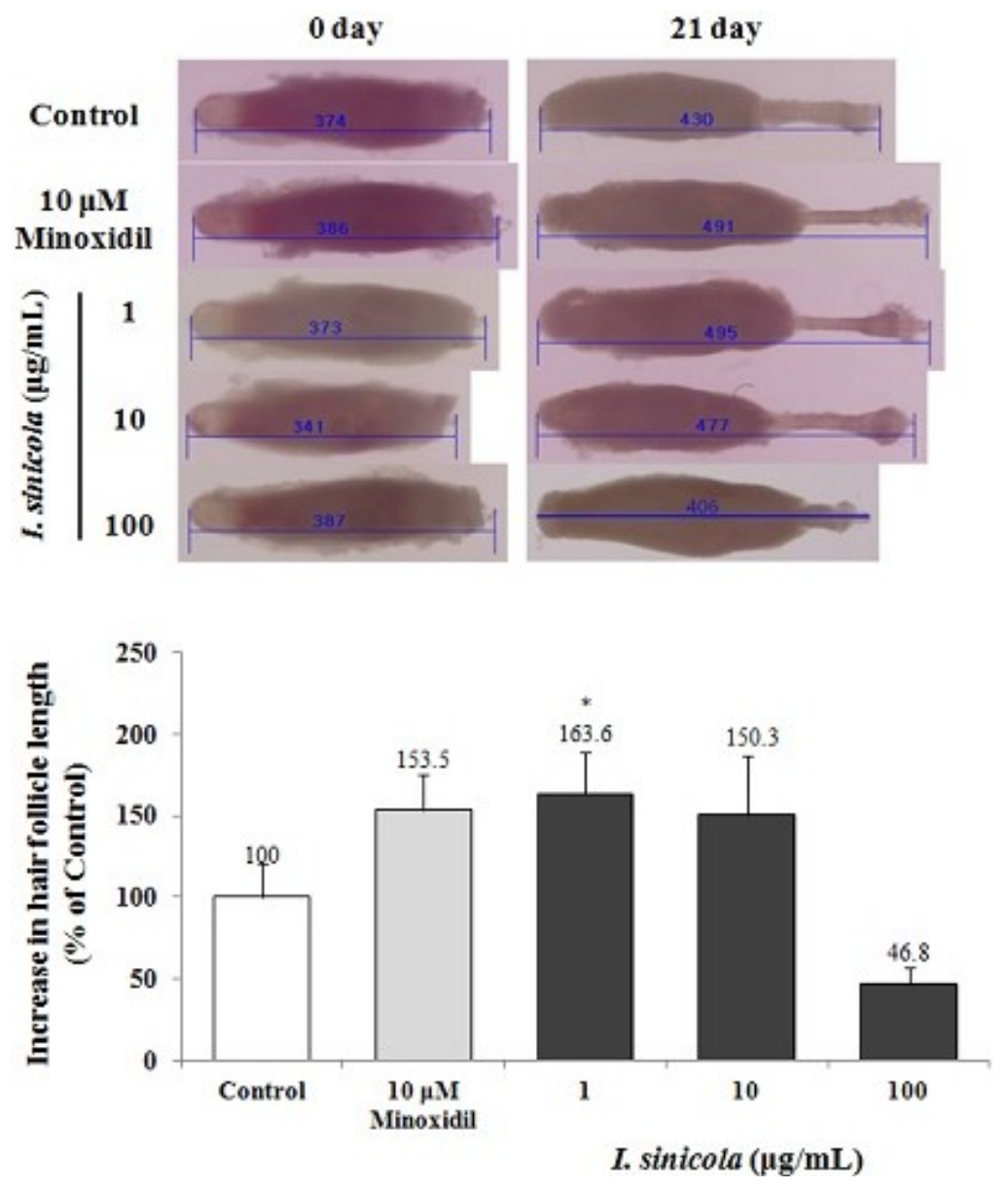

\subsection{The Effect of I. sinicola Extract on the Anagen Induction in C57BL/6 Mice}

To investigate whether anagen induction was promoted by $I$. sinicola extract, we used C57BL/6 mice, since the dorsal hair is known to have a time-synchronized hair growth cycle [25]. Shaved skin of telogen C57BL/6 mice is pink color, which then darkens along with anagen initiation. As shown in Figure 2, $10 \mu \mathrm{g} / \mathrm{mL}$ of $I$. sinicola extract-treated group showed gray skin at 19 days after depilation. When the area of black skin was analyzed with dotmatrix planimetry, the black skin area of the I. sinicola extract treated group was significantly larger than that of the control group at 34 days after depilation. The 5\% Minoxidil (Minoxidil ${ }^{\mathrm{TM}}$ ) treated group, a positive control group, exhibited gray skin from 12 days after depilation. These results indicate that I. sinicola extract promoted telogen-to-anagen transition in C57BL/6 mice. 
Figure 2. The effect of $I$. sinicola extract on the anagen induction in C57BL/6 mice. After shaving, the back skins were treated with I. sinicola extract, vehicle and 5\% minoxidil (MINOXYL ${ }^{\mathrm{TM}}$ ) every day for 34 days. (A) The back skins were photographed at 1, 12, 19, 26 and 34 days after depilation; (B) On day 34, to analyze the quantitative assessment of anagen induction, dotmatrix planimetry was performed. The transparency was put on a photo of a mouse to mark the areas that were in different stages (pink = telogen, anagen $=$ black). Afterward a dotmatrix (sheet with a uniform defined dot pattern) was placed under the marked foil to calculate the percentages of the regions of interest by counting the dots. The percentage of anagen induction was calculated by the equation [(black skin/total skin $) \times 100]$. Data are presented as the mean \pm S.E. $(n=8) .{ }^{*} p<0.05$, $* * p<0.01, * * * p<0.001 v s$. vehicle treated control.

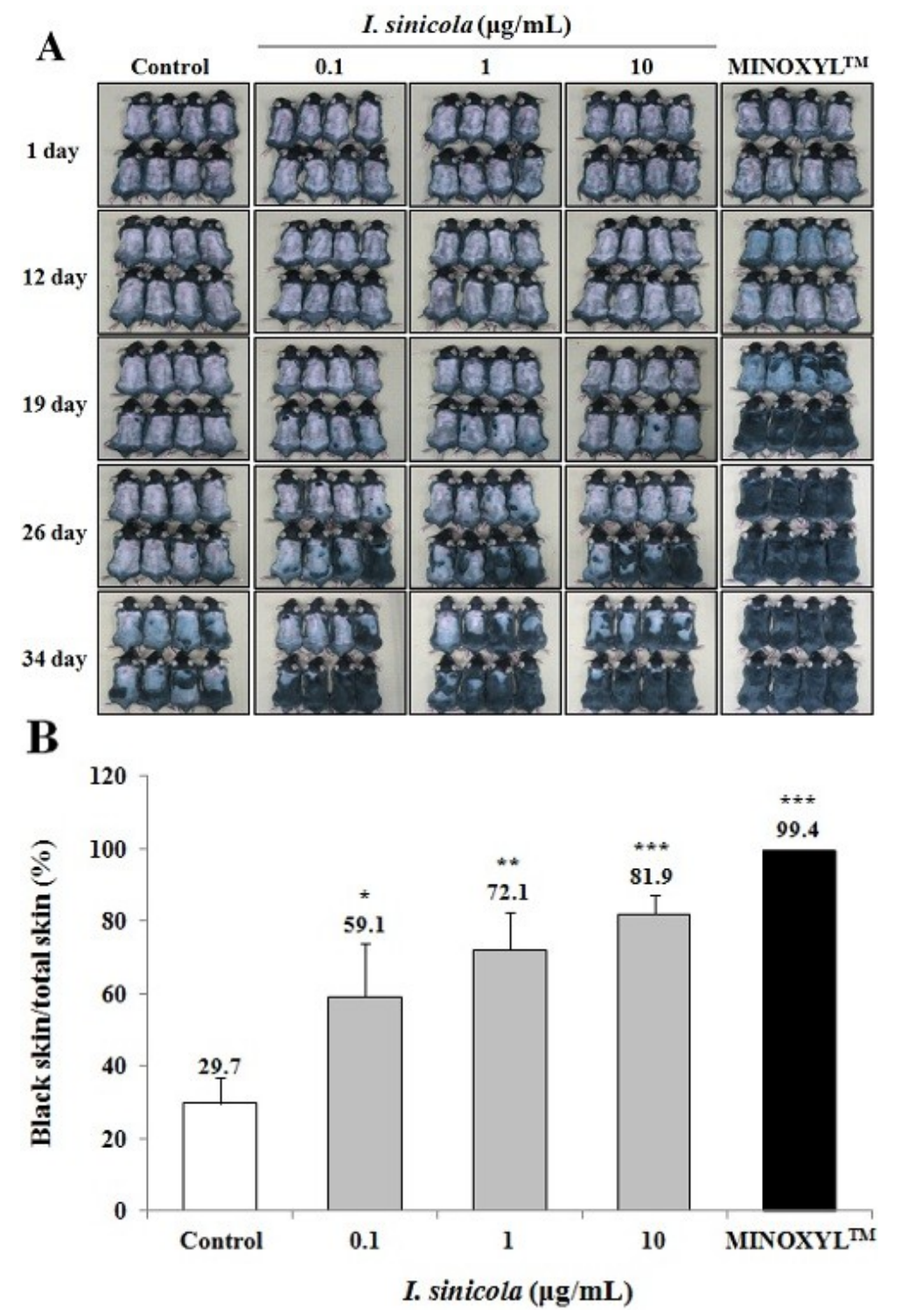

\subsection{Effects of I. sinicola Extract on the 5a-Reductase Activity and the Proliferation of DPCs}

$5 \alpha$-Reductase is an enzyme involved in conversion of testosterone to dihydrotestosterone (DHT) and a potential target of prevention of hair loss [26,27]. To determine whether I. sinicola extract could 
inhibit $5 \alpha$-reductase activity, we examined the $5 \alpha$-reductase activity with crude enzyme from rat prostate. As shown in Figure 3A, I. sinicola extract inhibited $5 \alpha$-reductase activities by $16.3 \%, 39.8 \%$ and $41.3 \%$ at the concentration of $0.1,1$ and $10 \mu \mathrm{g} / \mathrm{mL}$, respectively. Finasteride, a positive control, inhibited $5 \alpha$-reductase activity by above $84.5 \%$ at $2 \mathrm{nM}$ concentration. The results suggest that I. sinicola extract could have the potential for the treatment of AGA via the $5 \alpha$-reductase inhibition.

Figure 3. The effects of $I$. sinicola extract on the inhibition of $5 \alpha$-reductase and the proliferation of dermal papilla cells (DPCs). (A) Assay of $5 \alpha$-reductase inhibition was performed using crude extract of rat prostate as described in "Materials and Methods". The conversion rate of testosterone (T) to dihydrotestosterone (DHT) was calculated by the equation: $[\mathrm{DHT} /(\mathrm{T}+\mathrm{DHT})] \times 100$. Inhibition rate $(\%)$ was expressed as a percentage of reduced conversion rate compared to the control. The inhibition activity of control group was regarded as $0 \%$ (not shown). Finasteride was used as a positive control. (B) Immortalized vibrissa DPCs $\left(1.0 \times 10^{4}\right.$ cells $\left./ \mathrm{mL}\right)$ were plated in 96 well plates. DPCs were treated with various concentration of I. sinicola extract, as indicated. Cell proliferation was measured using a MTT assay for 4 days. Minoxidil $(10 \mu \mathrm{M})$ was used as a positive control. Data are presented as the mean \pm the S.D. of three independent experiments. $* p<0.05, * * p<0.01, * * * p<0.001$ vs. control.

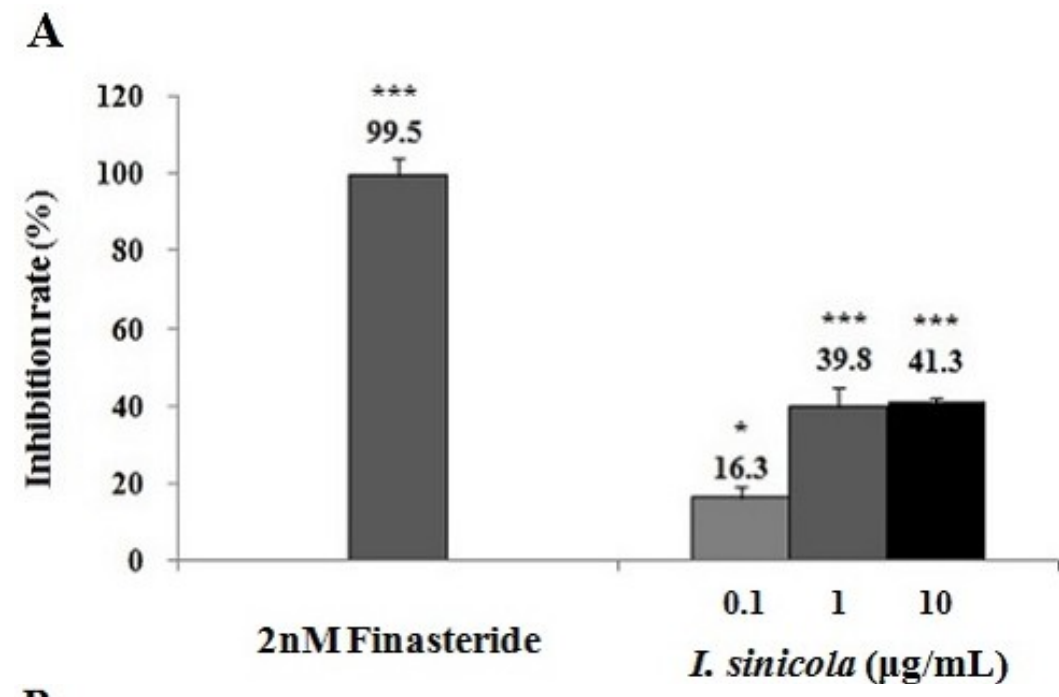

B

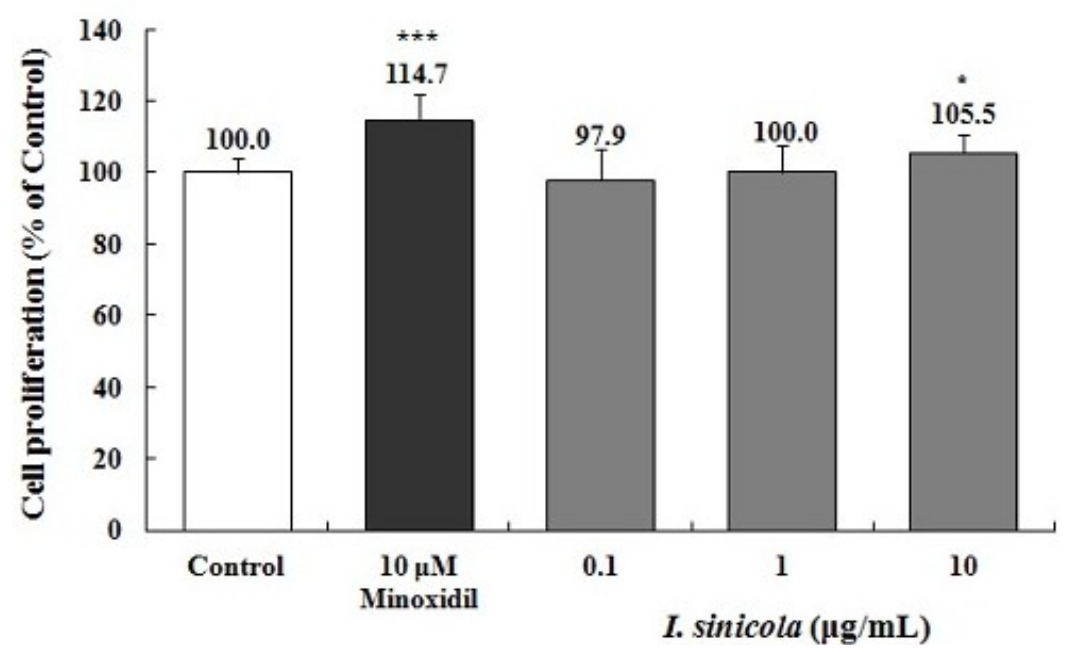


To evaluate the effect of $I$. sinicola extract on cell proliferation of hair follicles, DPCs were treated with various concentrations of I. sinicola extract. The I. sinicola extract promoted the proliferation of DPCs by $105.5 \%$ at the concentration of $10 \mu \mathrm{g} / \mathrm{mL}$ compared with the vehicle-treated control (Figure 3B). However, $100 \mu \mathrm{g} / \mathrm{mL}$ of $I$. sinicola extract inhibited the proliferation of dermal papilla cells compared to the control group (data not shown). The inhibition of DPC proliferation seems to result in the decrease of hair-fiber length (Figure 1). Minoxidil, a positive control, enhanced the proliferation of DPCs by $114.7 \%$ at the concentration of $10 \mu \mathrm{M}$ compared with the vehicle-treated control. The results suggest that I. sinicola extract might have hair-growth promoting effect via the proliferation of DPCs.

\subsection{Effects of I. sinicola Extract on the Expression Levels of Cell Cycle-Associated Proteins and $\beta$-Catenin}

Mammalian cells require activation of Cyclin E/CDK2 for cell cycle progression which is key process for cell proliferation [28]. Among cell cycle-associated proteins, p2 $7^{\text {kip1 }}$ binds to Cyclin E/CDK2 complexes and inhibits activation of Cyclin E/CDK2 [22,28]. In order to determine whether the proliferative effect of $I$. sinicola extract mediated by regulation of cell cycle proteins, we examined the expressions of $\mathrm{p} 27^{\mathrm{kip} 1}$, Cyclin E and CDK2 $(p<0.05)$. I. sinicola extract decreased the expression of p2 $7^{\mathrm{kip} 1}$, while increased the expressions of Cyclin E and CDK2 (Figure 4A). When treated with minoxidil $(10 \mu \mathrm{M})$, similar results were obtained (Figure $4 \mathrm{~A})$. On the other hand, Wnt/ $\beta$-catenin pathway plays an important role in hair growth [29], and has been implicated in the regulation of cell cycle proteins $[19,30]$. Activation of Wnt signaling pathway by phosphorylation of GSK3 $\beta$ induces the stabilization of $\beta$-catenin, which can cause nuclear translocation of $\beta$-catenin [31]. As shown in Figure 4B, when treated with I. sinicola extract, the level of $\beta$-catenin and the phosphorylation of GSK3 $\beta$ were increased. Minoxidil also increased the levels of $\beta$-catenin and the phospho-GSK3 $\beta$ $(p<0.05)$, compared to the control cells (Figure 4B). These results suggest that $I$. sinicola induced proliferation of DPCs via the regulation of cell cycle and Wnt/ $\beta$-catenin signaling. 
Figure 4. The I. sinicola extract regulates the levels of cell cycle associated proteins and the $\mathrm{Wnt} / \beta$-catenin signaling proteins in cultured DPCs. Immortalized vibrissa DPCs $\left(1.0 \times 10^{5}\right.$ cells $/ \mathrm{mL}$ in $100 \mathrm{~mm}$ dishes $)$ were pre-incubated for $24 \mathrm{~h}$ under $1 \%$ serum conditions, the cells were treated with $I$. sinicola extract ( 1 and $10 \mu \mathrm{g} / \mathrm{mL}$ ) and minoxidil $(\mathrm{MXD}, 10 \mu \mathrm{M})$ as a positive control for $24 \mathrm{~h}$. Whole cell lysates from DPCs were analyzed for (A) the levels of Cyclin E, CDK2 and p2 $7^{\text {kip1 }}$ as well as (B) the levels of phospho-GSK $3 \beta$, GSK $3 \beta$ and $\beta$-catenin by western blot. Lower panel displays mean \pm S.E. from three independent experiments. ${ }^{*} p<0.05$ vs. control.

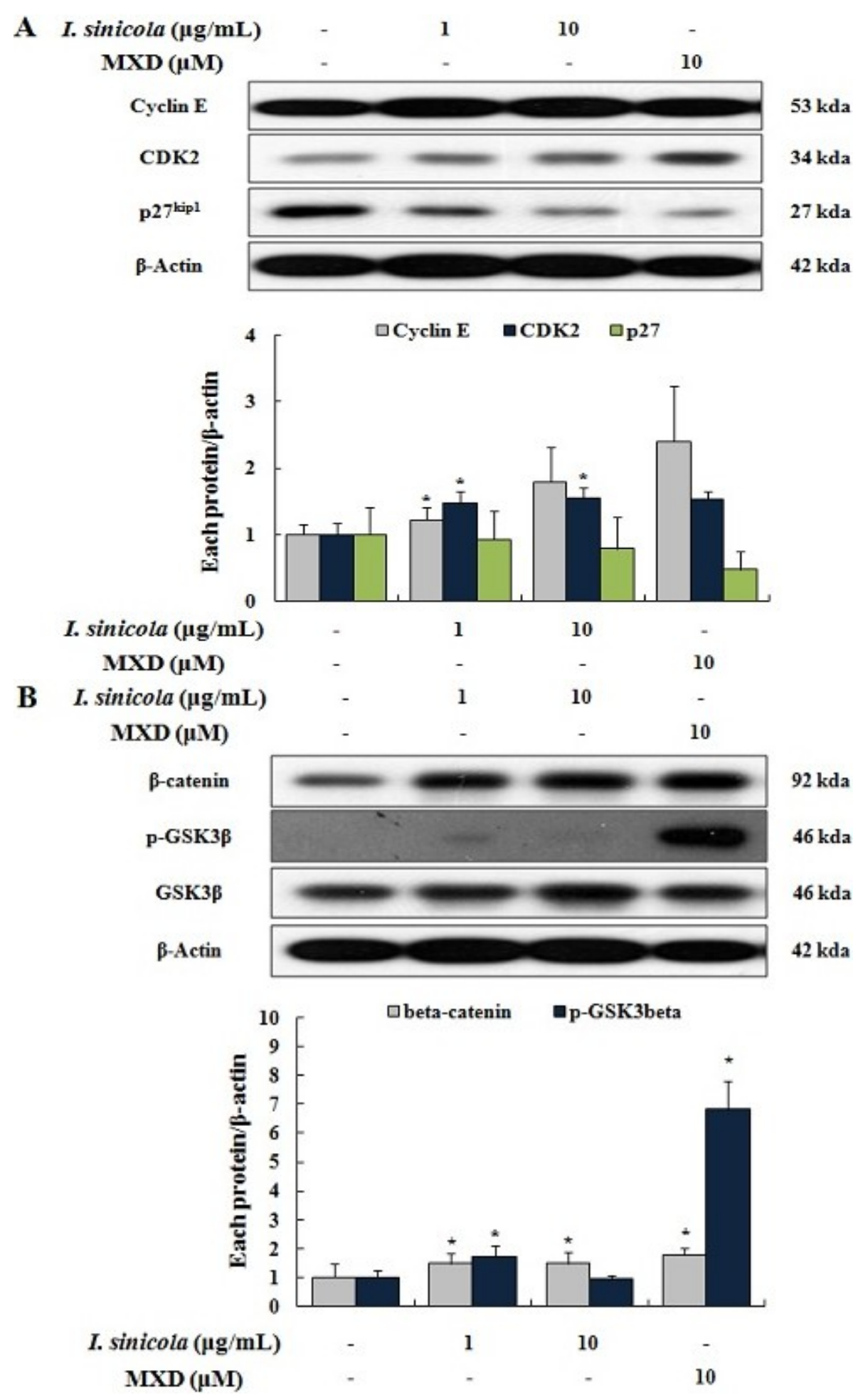




\subsection{Effect of Octaphlorethol A on the 5a-Reductase Activity and the Proliferation of DPCs}

To search the active components from $I$. sinicola extract on the promotion of hair growth, firstly, octaphlorethol A, a known component of I. sinicola, was examined. To evaluate whether octaphlorethol A could inhibit 5 $\alpha$-reductase activity, we examined the $5 \alpha$-reductase activity with crude enzyme from rat prostate. Octaphlorethol A inhibited $5 \alpha$-reductase activities by $29.1 \%, 27.5 \%$ and $20.9 \%$ at the concentration of $0.01,0.1$ and $1 \mu \mathrm{M}$, respectively (Figure 5A). Finasteride, a positive control, inhibited $5 \alpha$-reductase activities by above $84.5 \%$ at $2 \mathrm{nM}$ concentration. The results suggest that octaphlorethol A could have the potential for the treatment of AGA via the $5 \alpha$-reductase inhibition.

Figure 5. The effects of octaphlorethol A (OPA) on the inhibition of $5 \alpha$-reductase and the proliferation of DPCs. (A) Assay of $5 \alpha$-reductase inhibition was performed using crude extract of rat prostate as described in "Materials and Methods". The conversion rate of testosterone $(\mathrm{T})$ to dihydrotestosterone (DHT) was calculated by the equation $[\mathrm{DHT} /(\mathrm{T}+\mathrm{DHT})] \times 100$. Inhibition rate $(\%)$ was expressed as a percentage of reduced conversion rate compared to the control. The inhibition activity of control group was regarded as $0 \%$ (not shown). Finasteride was used as a positive control; (B) Immortalized vibrissa DPCs $\left(1.0 \times 10^{4}\right.$ cells $\left./ \mathrm{mL}\right)$ were plated in 96 well plates. DPCs were treated with various concentration of OPA, as indicated. Cell proliferation was measured using a MTT assay for 4 days. Minoxidil $(10 \mu \mathrm{M})$ was used as a positive control. Data are presented as the mean \pm the S.D. of three independent experiments. $* p<0.05, * * p<0.01$, $* * * p<0.001$ vs. control.

A

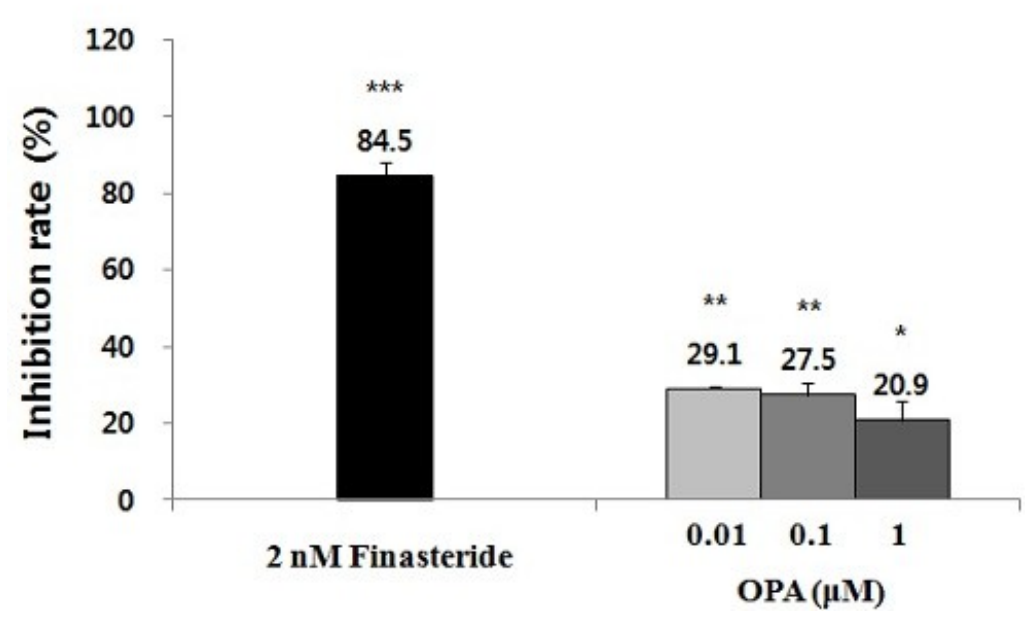


Figure 5. Cont.

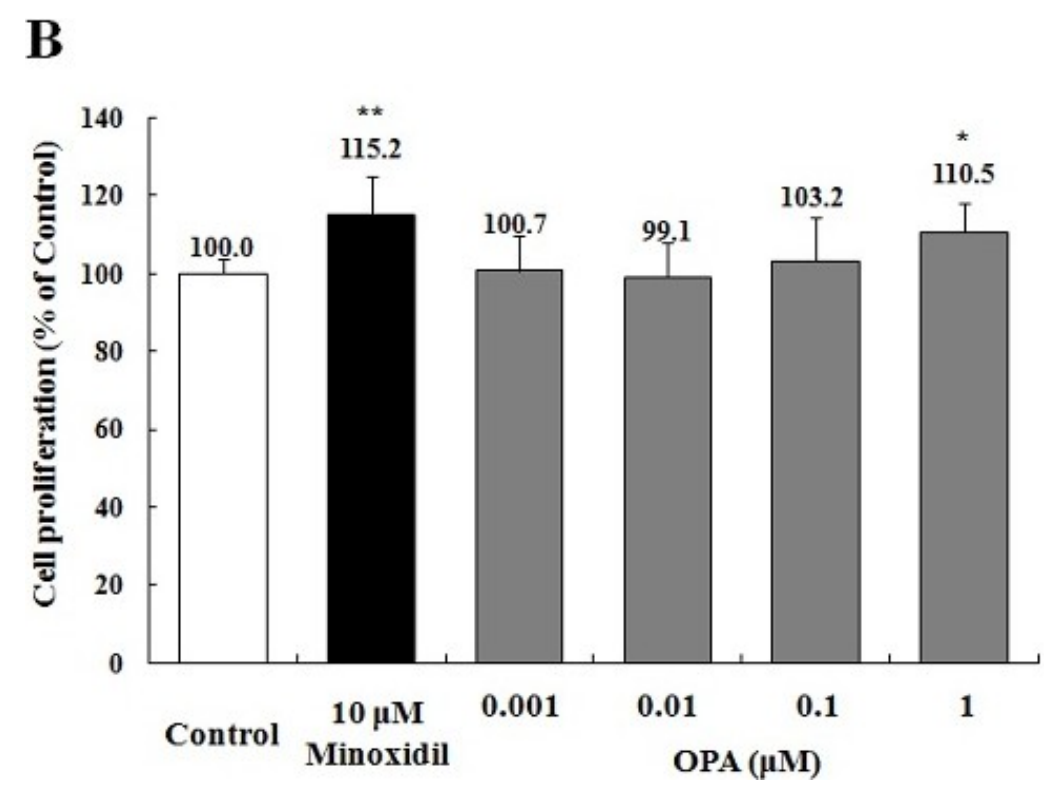

We also examined whether octaphlorethol A can also promote the proliferation of DPCs. Octaphlorethol A increased the proliferation of DPCs by 103 and $110.5 \%$ at the concentration of 0.1 and $1 \mu \mathrm{M}$ compared with the vehicle-treated control (Figure 5B). The results suggest that octaphlorethol A might have a hair-growth promoting effect via the proliferation of DPCs.

\section{Discussion}

In this study, the hair-growth promoting effects of $I$. sinicola extract and octaphlorethol A, a principal of I. sinicola extract, were investigated. To the best of our knowledge, this study is the first to demonstrate that I. sinicola extract and octaphlorethol A have the potential to treat alopecia via the proliferation of DPCs and $5 \alpha$-reductase inhibition.

To investigate hair-fiber elongation, we adopted rat vibrissa follicle culture model [32]. Vibrissa follicles from rats are much larger than pelage follicles and can be successfully cultured in vitro [33]. In particular, the hair growth cycles of the rat vibrissa follicles have been reported to be synchronized according to their age [33]. In addition, the isolated rat vibrissa follicles can be maintained in vitro up to 23 days [33]. In this study, we have isolated large posterior vibrissa follicles from 23 days old rats and maintained them for up to 21 days in vitro. In the continuing search for hair-growth promoting agents from natural sources, we found that the I. sinicola extract promoted the elongation of hair-fiber in cultured rat vibrissa follicles (Figure 1). To evaluate the in vivo effect of I. sinicola extract on the induction of the anagen phase, the hair growth promoting effect on C57BL/6 mouse was examined. As shown in Figure 2, I. sinicola extract promoted the anagen initiation of C57BL/6 mice in a dose-dependent manner.

AGA, the most common type of alopecia, can be modulated by the inhibition of $5 \alpha$-reductase, which converts testosterone to DHT $[2,4,34]$. Finasteride is known to repress the progression of AGA through inhibition of $5 \alpha$-reductase $[1,34]$. We found that I. sinicola extract and octaphlorethol A could inhibit the activity of $5 \alpha$-reductase (Figures 3 and 5). The results mean that $I$. sinicola extract and octaphlorethol A could have the potential for the treatment of AGA via the $5 \alpha$-reductase inhibition. 
The mesenchymally-derived dermal papilla cells play a pivotal role in hair growth regulation. The morphology of dermal papilla cells can be altered through the hair growth cycle, being maximal in volume in the growing phase (anagen) and least in the resting phase (telogen). Evidence has shown that the size of dermal papilla cells is well correlated with hair growth, and the cell number of dermal papilla cells is increased in the growing phase of hair cycle [35,36]. I. sinicola extract and octaphlorethol A increased the proliferation of DPCs compared with the control group (Figures 3 and 5). The results indicate that I. sinicola extract and octaphlorethol A might have hair-growth promoting effect via the proliferation of DPCs.

Progression of cell cycle is important event in the cell proliferation and is driven by cycle/CDKs complexes and CDK inhibitors [37,38]. As shown in Figure 4A, I. sinicola extract increased the expressions of Cyclin E and CDK2, whereas the expression of $\mathrm{p} 27^{\mathrm{kip} 1}$ decreased. Minoxidil treatment also showed similar results (Figure 4). These results suggest that $I$. sinicola extract and minoxidil increased the proliferation of DPCs via the regulation of cell cycle progression. Glibenclamide, a $\mathrm{K}_{\mathrm{ATP}}$ channel blocker, induced the cell cycle and inhibited cell proliferation by minoxidil, a $\mathrm{K}_{\mathrm{ATP}}$ channel opener [39]. Minoxidil is also known to induce hair growth through the activation of Wnt/ $\beta$-catenin pathway which is a known regulator of hair growth [10,16,17]. Our group also previously reported that acankoreoside $\mathrm{J}$ from Acanthopanax koreanum could increase hair growth through cell cycle progression and nuclear location of $\beta$-catenin [14]. The increase of GSK3 $\beta$ has been known to induce the activation and nuclear translocation of $\beta$-catenin [31]. In the present study, I. sinicola extract increased the levels of phospho-GSK3 $\beta$ and $\beta$-catenin (Figure 4B). These results are similar to other studies in which DPCs proliferation can be promoted by minoxidil or GSK3 $\beta$ inhibitor $[10,12,40]$. Therefore, our results indicate that proliferation of DPCs by I. sinicola extract can be promoted through the increase of Cyclin E, CDK2, $\beta$-catenin and phosph-GSK3 $\beta$, and the down-regulation of $\mathrm{p} 27^{\mathrm{kip} 1}$.

In the present study, we demonstrated that I. sinicola extract could promote hair growth in vitro and in vivo. Furthermore, I. sinicola extract increased the proliferation of DPCs via the up-regulation of Cyclin E, CDK2, $\beta$-catenin and phosph-GSK3 $\beta$, and the down-regulation of p2 $7^{\text {kip1 }}$. On the other hand, I. sinicola extract significantly inhibited the $5 \alpha$-reductase activity. In the course of searching the components promoting hair-growth, we found that octaphlorethol A, a known compound of I. sinicola, could increase the proliferation of DPCs and inhibit the $5 \alpha$-reductase activity. Our results indicate that octaphlorethol A can show both beneficial characteristics of minoxidil and finateride in the treatment of alopecia. The results suggest that I. sinicola extract and octaphlorethol A, a principal of I. sinicola, might help to treat alopecia via the proliferation of DPCs followed by the activation of $\beta$-catenin pathway, and the $5 \alpha$-reductase inhibition.

\section{Experimental Section}

\subsection{The Preparation of I. sinicola Extract and Isolation of Octaphlorethol A}

Ishige sinicola, a brown alga, was collected along the coast of Jeju Island, Korea, between Jun and July, 2010. The seaweed was washed three times with tap water to remove the salt, epiphytes, and sand attached to the surface, then carefully rinsed with fresh water and maintained in a medical refrigerator at $-20{ }^{\circ} \mathrm{C}$. Thereafter, the frozen sample was lyophilized and homogenized with a grinder prior to 
extraction. The powder $(500 \mathrm{~g})$ was extracted with $80 \%$ aqueous ethanol $(12 \mathrm{~L})$ at room temperature for $24 \mathrm{~h}$ and filtrated. After filtration, the $80 \%$ ethanol extract was evaporated to dryness under vacuum and used as I. sinicola extract. Octaphlorethol A was isolated according to methods described in previous report [24]. The I. sinicola extract and octaphlorethol A were dissolved in dimethyl sulfoxide (DMSO) (Sigma, St. Louise, MO, USA) for subsequent treatment adjusting the final concentration of DMSO in culture medium to $<0.2 \%$.

\subsection{Animals}

Three-Week-old male Wistar rats, 6-week-old female C57BL/6 mice and 8-week-old male spargue-Dawley (SD) rats were supplied from Orient Bio (Seongnam, Gyeonggi, Korea). All animals provided with a standard laboratory diet and water ad libitum. All animals were cared for by using protocols (20100031) approved by the Institutional Animal Care and Use Committee (IACUC) of the Jeju National University.

\subsection{Isolation and Culture of Rat Vibrissa Follicles}

Isolation of rat vibrissa follicles was performed as described previously [33]. Briefly, rat vibrissa follicles were harvested from male Wistar rats that were 23 days old. To accomplish this, the rats were sacrificed under carbon dioxide $\left(\mathrm{CO}_{2}\right)$. Next, both the left and right mystacial pads were removed from the rats and placed in a 1:1 (v/v) solution of Earle's balanced salts solution (EBSS; Sigma) and PBS that contained $100 \mathrm{unit} / \mathrm{mL}$ of penicillin and $100 \mu \mathrm{g} / \mathrm{mL}$ of streptomycin. Anagen vibrissa follicles were then carefully dissected under a stereomicroscope (Olympus, Tokyo, Japan) from posterior parts of the mystacial pads with considerable care being taken to remove the surrounding connective tissue without damaging the vibrissa follicle. Using this method we were able to routinely isolate more than 40 follicles from each animal. The isolated follicles were then placed in separate wells in 24-well plates that contained $500 \mu \mathrm{L}$ of Williams medium E (Gibco, Grand Island, NY, USA) supplemented with $2 \mathrm{mM}$ L-glutamine (Gibco, NY, USA), $10 \mu \mathrm{g} / \mathrm{mL}$ insulin (Sigma), $50 \mathrm{nM}$ hydrocortisone (Sigma), 100 unit $/ \mathrm{mL}$ penicillin and $100 \mu \mathrm{g} / \mathrm{mL}$ streptomycin at $37{ }^{\circ} \mathrm{C}$ and cultivated in an atmosphere comprised of $5 \% \mathrm{CO}_{2}$ and $95 \%$ air. The isolated follicles were then treated with vehicle (DMSO diluted 1:1000 in Williams medium E) as a control and I. sinicola extract (1, 10 and $100 \mu \mathrm{g} / \mathrm{mL})$. Minoxidil (Sigma) was used as a positive control in the culture systems [41]. The culture medium was changed every 3 days and photographs of the cultured rat vibrissa follicles were taken using a stereomicroscope for 3 weeks. The length of the hair follicles was measured using a DP controller (Olympus, Tokyo, Japan).

\subsection{Hair Growth Activity in Vivo}

Anagen was induced on the back skin of C57BL/6 mice that were in the telogen phase of the cycle by depilation, as described previously [25]. Briefly, 6-week-old female C57BL/6 mice were allowed to adapt to their new environment for one week. The anagen was then induced in the back skin of the 7-week-old female C57BL/6 mice by shaving, which led to synchronized development of anagen hair follicles. From the following day (day 1), $0.2 \mathrm{~mL}$ of $I$. sinicola extract in $50 \%$ ethanol was topically 


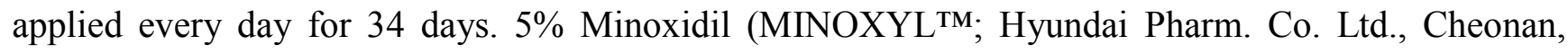
Chungnam, Korea) was used as a positive control. The back skin of the mice was then observed and photographed at 1, 12, 19, 26 and 34 days after shaving. For the quantitative assessment, dotmatrix planimetry was performed [42].

\subsection{Assay for Prostatic 5a-Reductase Activity}

Male SD rats (8 week old) were sacrificed with $\mathrm{CO}_{2}$. The rat prostates were removed from their capsules, washed with saline, and stored at $-80{ }^{\circ} \mathrm{C}$. Frozen tissues were thawed on ice and procedures were carried out at $4{ }^{\circ} \mathrm{C}$. The tissues were homogenized with a Polytron homogenizer (Brinkman Instruments, Westbury, NY, USA) in 5-6 tissue volumes of medium A (0.32 M sucrose, $1 \mathrm{mM}$ dithiothreitol (DTT), $0.2 \mathrm{mM}$ phenylmethylsulfonylfluoride (PMSF); and $20 \mathrm{mM}$ potassium phosphate buffer, $\mathrm{pH}$ 6.6). The homogenates were centrifuged at $1500 \mathrm{~g}$ for $20 \mathrm{~min}$. The pellets were recovered, washed with three tissue volumes of medium A, and centrifuged two additional times at $400 \mathrm{~g}$ for $10 \mathrm{~min}$. The washed pellets were suspended in medium $\mathrm{A}$ and stored at $-80{ }^{\circ} \mathrm{C}$ until use. The suspension ( $2.5 \mathrm{mg}$ protein $/ \mathrm{mL}$ as determined by the Bradford assay using Bio-Rad reagents) was used as source of $5 \alpha$-reductase. $5 \alpha$-reductase activities were analyzed as previously described [43]. The reaction mixture had a final volume of $500 \mu \mathrm{L}$ and contained $1 \mathrm{mM}$ DTT, $40 \mathrm{mM}$ potassium phosphate buffer, $\mathrm{pH}$ 6.6, $2 \mathrm{mM} \mathrm{NADPH}$, and $120 \mathrm{nCi}\left[1,2,6,7-{ }^{3} \mathrm{H}\right]$ testosterone. Triplicate reactions were initiated when the reaction mixture was added to the rat prostatic enzyme fraction ( $250 \mu \mathrm{g}$ of protein) containing 0.2\% DMSO (as a control), I. sinicola extract $(0.1,1$ and $10 \mu \mathrm{g} / \mathrm{mL}$ ), or octaphlorethol A (0.01, 0.1 and $1 \mu \mathrm{M})$. Finasteride $2 \mathrm{nM}$ (Merck-Sharpe-Dohme, Granville, NJ, USA) was used as a positive control. The mixture was incubated at $37^{\circ} \mathrm{C}$ for $60 \mathrm{~min}$, and then stopped by adding $1 \mathrm{~mL}$ of ethyl acetate and mixing for $1 \mathrm{~min}$. After centrifugation at $1000 \mathrm{~g}$ for $5 \mathrm{~min}$, the organic phase was removed, dried under a heating plate, dissolved in $50 \mu \mathrm{L}$ of ethyl acetate containing $500 \mu \mathrm{g} / \mathrm{mL}$ of testosterone and $500 \mu \mathrm{g} / \mathrm{mL}$ of DHT, and applied to a silica gel 60 F254 TLC plate (Merck). The plate was developed in a solvent system consisting of an ethyl acetate:cyclohexane (1:1) solution, and the plate was air dried. Testosterone was visualized under UV light (254 nm) and DHT was detected using a $10 \% \mathrm{H}_{2} \mathrm{SO}_{4}$ solution and posteriorly heating the plate. Under these conditions, DHT develops a classical dark yellow color. Areas containing androgen were removed and the strips were soaked in $5 \mathrm{~mL}$ of ULTIMA GOLD ${ }^{\mathrm{TM}}$ Cocktail (PerkinElmer, Boston, MA, USA) and radioactivity was measured by a liquid scintillation counter (Packard Bioscience, Meriden, CT, USA). The activity of $5 \alpha$-reductase was expressed as a ratio calculated by the equation: $[\mathrm{DHT} /(\mathrm{T}+\mathrm{DHT})] \times 100$.

\subsection{Assay for the Proliferation of DPCs}

Rat vibrissa immortalized dermal papilla cell (DPCs) [44] was donated by the Skin Research Institute, Amore Pacific Corporation R \& D Center, Korea. The DPCs were cultured in DMEM (Hyclone Inc., Logan, UT, USA) supplemented with 10\% fetal bovine serum (FBS; Gibco, Grand Island, NY, USA) and penicillin/streptomycin (100 unit/mL and $100 \mu \mathrm{g} / \mathrm{mL}$, respectively) at $37{ }^{\circ} \mathrm{C}$ in a humidified atmosphere under $5 \% \mathrm{CO}_{2}$.

The proliferation of DPCs was evaluated by measuring the metabolic activity using a 3-[4,5-dimethylthiazol-2-yl]-2,5-diphenyltetrazolium bromide (MTT) assay [45]. Briefly, DPCs at 
$1.0 \times 10^{4}$ cells $/ \mathrm{mL}$ were seeded into 96 -well plate, cultured for $24 \mathrm{~h}$ under $1 \%$ serum conditions, and then treated with vehicle (DMSO diluted 1:1000 in serum-free DMEM) as a control, the I. sinicola extract $(0.1,1$ and $10 \mu \mathrm{g} / \mathrm{mL})$, and octaphlorethol $\mathrm{A}(0.001,0.01,0.1$ and $1 \mu \mathrm{M})$ for 4 days. After incubation, $0.1 \mathrm{mg}$ ( $50 \mu \mathrm{L}$ of a $2 \mathrm{mg} / \mathrm{mL}$ solution) of MTT (Sigma) was added to each well, and the cells were then incubated at $37^{\circ} \mathrm{C}$ for $4 \mathrm{~h}$. Next, the plates were centrifuged at $1000 \mathrm{rpm}$ for $5 \mathrm{~min}$ at room temperature and the media was then carefully aspirated. DMSO $200 \mu \mathrm{L}$ was then added to each well to dissolve the formazan crystals and the absorbance of the plate at $540 \mathrm{~nm}$ was then read immediately on a microplate reader (BioTek Instrument Inc., Winooski, VT, USA). All experiments were performed three times and the mean absorbance values were calculated. The results are expressed as the percentage in the absorbance caused by treatment with I. sinicola extract or octaphlorethol A compared to that of the untreated controls. Minoxidil (Sigma) was used as a positive control.

\subsection{Western Blot Analysis}

The DPCs $\left(1.0 \times 10^{5}\right.$ cells $/ \mathrm{mL}$ in $100 \mathrm{~mm}$ dishes $)$ were pre-incubated for $24 \mathrm{~h}$ under $1 \%$ serum conditions, and the cells were treated with $I$. sinicola extract ( 1 and $10 \mu \mathrm{g} / \mathrm{mL})$ and minoxidil $(10 \mu \mathrm{M})$ as a positive control for $24 \mathrm{~h}$. The cells were washed twice with ice-cold PBS. The cells were lysed in lysis buffer [50 mM Tris- $\mathrm{HCl}(\mathrm{pH} 7.5), 150 \mathrm{mM} \mathrm{NaCl}, 2 \mathrm{mM}$ EDTA, $1 \mathrm{mM}$ EGTA, $1 \mathrm{mM} \mathrm{NaVO}$, $10 \mathrm{mM} \mathrm{NaF}, 1 \mathrm{mM}$ dithiothreitol (DTT), $1 \mathrm{mM}$ phenylmethylsulfonylfluoride (PMSF), $25 \mu \mathrm{g} / \mathrm{mL}$ aprotinin, $25 \mu \mathrm{g} / \mathrm{mL}$ leupeptin and 1\% NP-40] to obtain whole cell protein and kept on ice for $30 \mathrm{~min}$. The cell lysates were centrifuged at $15,000 \mathrm{rpm}$ at $4{ }^{\circ} \mathrm{C}$ for $15 \mathrm{~min}$. Supernatants were stored at $-20{ }^{\circ} \mathrm{C}$ until analysis. Protein concentration was determined by the Bradford method [46]. Equal amounts of protein were separated on $8 \%-12 \%$ Sodium dodecyl sulfate polyacrylamide gel electrophoresis (SDS-PAGE) gels. And then proteins were transferred onto polyvinylidene fluoride (PVDF) membranes (Bio-Rad, Hercules, CA, USA) with a glycine transfer buffer [192 mM glycine, $25 \mathrm{mM}$ Tris- $\mathrm{HCl}(\mathrm{pH} 8.8), 20 \% \mathrm{MeOH}(\mathrm{v} / \mathrm{v})]$ at $100 \mathrm{~V}$ for $2 \mathrm{~h}$. After blocking with 5\% nonfat dried milk in Tween-20-TBS (T-TBS) (50 mM Tris, pH 7.6, $150 \mathrm{mM} \mathrm{NaCl}, 0.1 \%$ Tween-20), each membrane was incubated with specific primary antibodies against CDK2 (1:2000), Cyclin E $(1: 2000)$, p2 $7^{\text {kip } 1}$ (1:1000), phospho-GSK3 $\beta$ (1:1000), GSK3 $\beta$ (1:1000), $\beta$-catenin $(1: 2000)$ and $\beta$-actin $(1: 5000)$ at $4{ }^{\circ} \mathrm{C}$ overnight. The membrane was incubated with a secondary HRP antibody (1:5000) at room temperature for $1 \mathrm{~h}$. The membrane was exposed on X-ray film (AGFA, Mortsel, Belgium), and protein bands were detected using West-zol (Intron, Seoul, Korea). Band intensities were quantified with the NIH Image software.

\subsection{Statistical Analysis}

Results are expressed as the mean \pm the standard deviation (S.D.) or standard errors (S.E.) of at least three independent experiments. The Student's $t$-test was used to determine the statistical significance $(p<0.05)$ of the differences between the values for the various experimental and control groups. 


\section{Conclusions}

In conclusion, the results of this study demonstrated that I. sinicola extract and octaphlorethol A are capable of preventing hair loss via the proliferation of DPCs and $5 \alpha$-reductase inhibition. These findings provide a possibility for the development of octaphlorethol A, a principal of $I$. sinicola, as a therapeutic agent for the treatment of hair loss.

\section{Acknowledgments}

This research was a part of the project titled "Development of Product and Material Promoting Hair-Growth from Jeju Marine Algae" funded by the Ministry of Land, Transport and Maritime Affairs, Korea.

\section{Conflict of Interest}

The authors declare no conflict of interest.

\section{References}

1. Price, V.H. Treatment of hair loss. N. Engl. J. Med. 1999, 341, 964.

2. Kaufman, K.D.; Olsen, E.A.; Whiting, D.; Savin, R.; DeVillez, R.; Bergfeld, W.; Price, V.H.; van Neste, D.; Roberts, J.L.; Hordinsky, M.; et al. Finasteride in the treatment of men with androgenetic alopecia. J. Am. Acad. Dermatol. 1998, 39, 578-589.

3. Burton, J.L.; Marshall, A. Hypertrichosis due to minoxidil. Br. J. Dermatol. 1979, 101, 593-595.

4. Gromley, G.J. Finasteride: A clinical review. Biomed. Pharmacother. 1995, 49, 319-324.

5. Kaufman, K.D.; Rotonda, J.; Shah, A.K.; Meehan, A.G. Long-term treatment with finasteride $1 \mathrm{mg}$ decreases the likelihood of developing further visible hair loss in men with androgenetic alopecia (male pattern hair loss). Eur. J. Dermatol. 2008, 18, 400-406.

6. Van Neste, D.; Fuh, V.; Sanchez-Pedreno, P.; Lopez-Bran, E.; Wolff, H.; Whiting, D.; Roberts, J.; Kopera, D.; Stene, J.J.; Calvieri, S.; et al. Finasteride increases anagen hair in men with androgenetic alopecia. Br. J. Dermatol. 2000, 143, 804-810.

7. Hamaoka, H.; Minakuchi, K.; Miyoshi, H.; Arase, S.; Chen, C.H.; Nakaya, Y. Effect of K ${ }^{+}$ channel openers on $\mathrm{K}^{+}$channel in cultured human dermal papilla cells. J. Med. Invest. 1997, 44, 73-77.

8. Shorter, K.; Farjo, N.P.; Picksley, S.M.; Randall, V.A. Human hair follicles contain two forms of ATP-sensitive potassium channels, only one of which is sensitive to minoxidil. FASEB J. 2008, 22, 1725-1736.

9. Lachgar, S.; Charveron, M.; Gall, Y.; Bonafe, J.L. Minoxidil upregulates the expression of vascular endothelial growth factor in human hair dermal papilla cells. Br. J. Dermatol. 1998, 138, 407-411.

10. Kwack, M.H.; Kang, B.M.; Kim, M.K.; Kim, J.C.; Sung, Y.K. Minoxidil activates beta-catenin pathway in human dermal papilla cells: A possible explanation for its anagen prolongation effect. J. Dermatol. Sci. 2011, 62, 154-159.

11. Stenn, K.S.; Paus, R. Controls of hair follicle cycling. Physiol. Rev. 2001, 81, 449-494. 
12. Han, J.H.; Kwon, O.S.; Chung, J.H.; Cho, K.H.; Eun, H.C.; Kim, K.H. Effect of minoxidil on proliferation and apoptosis in dermal papilla cells of human hair follicle. J. Dermatol. Sci. 2004, 34, 91-98.

13. Kim, S.C.; Kang, J.I.; Park, D.B.; Lee, Y.K.; Hyun, J.W.; Koh, Y.S.; Yoo, E.S.; Kim, J.A.; Kim, Y.H.; Kang, H.K. Promotion effect of Acankoreoside J, a lupane-triterpene in Acanthopanax koreanum, on hair growth. Arch. Pharm. Res. 2012, 35, 1495-1503.

14. Park, P.J.; Moon, B.S.; Lee, S.H.; Kim, S.N.; Kim, A.R.; Kim, H.J.; Park, W.S.; Choi, K.Y.; Cho, E.G.; Lee, T.R. Hair growth-promoting effect of Aconiti Ciliare Tuber extract mediated by the activation of Wnt/ $\beta$-catenin signaling. Life Sci. 2012, 91, 935-943.

15. Park, S.; Shin, W.S.; Ho, J. Fructus panax ginseng extract promotes hair regeneration in C57BL/6 mice. J. Ethnopharmacol. 2011, 138, 340-344.

16. Ito, M.; Yang, Z.; Andl, T.; Cui, C.; Kim, N.; Millar, S.E.; Cotsarelis, G. Wnt-dependent de novo hair follicle regeneration in adult mouse skin after wounding. Nature 2007, 447, 316-320.

17. Ouji, Y.; Yoshikawa, M.; Shiroi, A.; Ishizaka, S. Promotion of hair follicle development and trichogenesis by Wnt-10b in cultured embryonic skin and in reconstituted skin. Biochem. Biophys. Res. Commun. 2006, 345, 581-587.

18. Rulifson, I.C.; Karnik, S.K.; Heiser, P.W.; Ten Berge, D.; Chen, H.; Gu, X.; Taketo, M.M.; Nusse, R.; Hebrok, M.; Kim, S.K. Wnt signaling regulates pancreatic beta cell proliferation. Proc. Natl. Acad. Sci. USA 2007, 104, 6247-6252.

19. Tetsu, O.; McCormick, F. Beta-catenin regulates expression of cyclin D1 in colon carcinoma cells. Nature 1999, 398, 422-426.

20. He, T.C.; Sparks, A.B.; Rago, C.; Hermeking, H.; Zawel, L.; da Costa, L.T.; Morin, P.J.; Vogelstein, B.; Kinzler, K.W. Identification of c-MYC as a target of the APC pathway. Science 1998, 281, 1509-1512.

21. Johnson, D.G.; Walker, C.L. Cyclins and cell cycle checkpoints. Annu. Rev. Pharmacol. Toxicol. 1999, 39, 295-312.

22. Sherr, C.J. Cancer cell cycles. Science 1996, 274, 1672-1677.

23. Choi, J.S.; Bae, H.J.; Kim, S.J.; Choi, I.S. In vitro antibacterial and anti-inflammatory properties of seaweed extracts against acne inducing bacteria, Propionibacterium acnes. J. Environ. Biol. 2011, 32, 313-318.

24. Lee, S.H.; Kang, S.M.; Ko, S.C.; Lee, D.H.; Jeon, Y.J. Octaphlorethol A, a novel phenolic compound isolated from a brown alga, Ishige foliacea, increases glucose transporter 4-mediated glucose uptake in skeletal muscle cells. Biochem. Biophys. Res. Commun. 2012, 420, 576-581.

25. Müller-Röver, S.; Handjiski, B.; van der Veen, C.; Maurer, M.; Eichmüller, S.; Ling, G.; Hofmann, U.; Foitzik, K.; Mecklenburg, L.; Handjiski, B. A comprehensive guide for the accurate classification of murine hair follicles in distinct hair cycle stages. J. Invest. Dermatol. 2001, 117, 3-15.

26. Whiting, D.A. Male pattern hair loss: Current understanding. Int. J. Dermatol. 1998, 37, 561-566.

27. Trüeb, R.M. Molecular mechanisms of androgenetic alopecia. Exp. Gerontol. 2002, 37, 981-990.

28. Sherr, C.J.; Roberts, J.M. CDK inhibitors: Positive and negative regulators of G1-phase progression. Genes Dev. 1999, 13, 1501-1512. 
29. Ouji, Y.; Yoshikawa, M.; Moriya, K.; Ishizaka, S. Effects of Wnt-10b on hair shaft growth in hair follicle cultures. Biochem. Biophys. Res. Commun. 2007, 359, 516-522.

30. Wangefjord, S.; Brändstedt, J.; Ericson Lindquist, K.; Nodin, B.; Jirström, K.; Eberhard, J. Associations of beta-catenin alterations and MSI screening status with expression of key cell cycle regulating proteins and survival from colorectal cancer. Diagn. Pathol. 2013, 8, 10.

31. Hedgepeth, C.M.; Conrad, L.J.; Zhang, J.; Huang, H.C.; Lee, V.M.; Klein, P.S. Activation of the Wnt signaling pathway: A molecular mechanism for lithium action. Dev. Biol. 1997, 185, 82-91.

32. Philpott, M.P.; Green, M.R.; Kealy, T. Rat hair follicle growth in vitro. Br. J. Dermatol. 1992, 127, 600-607.

33. Philpott, M.P.; Kealey, T. Cyclical changes in rat vibrissa follicles maintained in vitro. J. Invest. Dermatol. 2000, 115, 1152-1155.

34. Kaufman, K.D. Androgen metabolism as it affects hair growth in androgenetic alopecia. Dermatol. Clin. 1996, 14, 697-711.

35. Jahoda, C.A.; Horne, K.A.; Oliver, R.F. Induction of hair growth by implantation of cultured dermal papilla cells. Nature 1984, 311, 560-562.

36. Elliott, K.; Stephenson, T.J.; Messenger, A.G. Differences in hair follicle dermal papilla volume are due to extracellular matrix volume and cell number: Implications for the control of hair follicle size and androgen responses. J. Invest. Dermatol. 1999, 113, 873-877.

37. Igata, M.; Motoshima, H.; Tsuruzoe, K.; Kojima, K.; Matsumura, T.; Kondo, T.; Taguchi, T.; Nakamaru, K.; Yano, M.; Kukidome, D. Adenosine monophosphate-activated protein kinase suppresses vascular smooth muscle cell proliferation through the inhibition of cell cycle progression. Circ. Res. 2005, 97, 837-844.

38. Prall, O.W.; Sarcevic, B.; Musgrove, E.A.; Watts, C.K.; Sutherland, R.L. Estrogen-induced activation of $\mathrm{Cdk} 4$ and $\mathrm{Cdk} 2$ during G1-S phase progression is accompanied by increased cyclin D1 expression and decreased cyclin-dependent kinase inhibitor association with cyclin E-Cdk2. J. Biol. Chem. 1997, 272, 10882-10894.

39. Núñez, M.; Medina, V.; Cricco, G.; Croci, M.; Cocca, C.; Rivera, E.; Bergoc, R.; Martín, G. Glibenclamide inhibits cell growth by inducing G0/G1 arrest in the human breast cancer cell line MDA-MB-231. BMC Pharmacol. Toxicol. 2013, 14, 6.

40. Yamauchi, K.; Kurosaka, A. Inhibition of glycogen synthase kinase-3 enhances the expression of alkaline phosphatase and insulin-like growth factor-1 in human primary dermal papilla cell culture and maintains mouse hair bulbs in organ culture. Arch. Dermatol. Res. 2009, 301, 357-365.

41. Buhl, A.E.; Waldon, D.J.; Kawabe, T.T.; Holland, J.M. Minoxidil stimulates mouse vibrissae follicles in organ culture. J. Invest. Dermatol. 1989, 6, 129-131.

42. Ohnemus, U.; Uenalan, M.; Conrad, F.; Handjiski, B.; Mecklenburg, L.; Nakamura, M.; Inzunza, J.; Gustafsson, J.A.; Paus, R. Hair cycle control by estrogens: Catagen induction via estrogen receptor (ER)-alpha is checked by ER beta signaling. Endocrinology 2005, 146, 1214-1225.

43. Hirosumi, J.; Nakayama, O.; Fagan, T.; Sawada, K.; Chida, N.; Inami, M.; Takahashi, S.; Notsu, Y.; Okuhara, M.J. FK143, a novel nonsteroidal inhibitor of steroid 5-reductase: (1) In vitro effects on human and animal prostatic enzymes. J. Steroid Biochem. Mol. Biol. 1995, 52, 357-363. 
44. Filsell, W.; Little, J.C.; Stones, A.J.; Granger, S.P.; Bayley, S.A. Transfection of rat dermal papilla cells with a gene encoding a temperature-sensitive polyomavirus large $\mathrm{T}$ antigen generates cell lines a differentiated phenotype. J. Cell Sci. 1994, 107, 1761-1772.

45. Carmichael, J.; DeGraff, W.G.; Gazdar, A.F.; Minna, J.D.; Mitchell, J.B. Evaluation of a tetrazolium-based semiautomated colorimetric assay: Assessment of chemosensitivity testing. Cancer Res. 1987, 47, 936-942.

46. Bradford, M.M. A rapid and sensitive method for the quantitation of microgram quantities of protein utilizing the principle of protein-dye binding. Anal. Biochem. 1976, 72, 248-254.

(C) 2013 by the authors; licensee MDPI, Basel, Switzerland. This article is an open access article distributed under the terms and conditions of the Creative Commons Attribution license (http://creativecommons.org/licenses/by/3.0/). 